At-Taradhi: Jurnal Studi Ekonomi

Volume XI Nomor 1, Juni 2020

P-ISSN: 1979-3804, E-ISSN: 2548-9941

\title{
Pengaruh Persepsi Dan Religiusitas Terhadap Pembelian Skin Care Tanpa Label Halal Pada Muslim Generasi Z di Banjarmasin
}

\section{Firqah Annajiyah Mansyuroh}

Pascasarjana Universitas Islam Antasari, Indonesia. E-mail: firqahannajiyahmansyuroh@,gmail.com

\section{ARTICLE INFO}

Kata Kunci:
Consumer Behaviour;
Perception; Planned
Behaviour; Religiosity

\section{Cara Sitasi:}

Mansyurah, Firqah Annajiyah. "Pengaruh Persepsi Dan Religiusitas Terhadap Pembelian Skin Care Tanpa Label Halal Pada Muslim Generasi Z di Banjarmasin." AtTaradhi: Jurnal Studi Ekonomi 11, no. 1 (2020): 46-66.

\begin{abstract}
Muslims need to consume halal goods, including consumption of skin care products for facial care. Although the majority of Indonesia's population is Muslim, there are not many products that are halal-certified. The purpose of this study was to determine the factors that influence the purchasing decisions of skin care consumers of generation $Z$ Muslims without the halal label in Banjarmasin. This research is a quantitative study with 145 Banjarmasin generation $Z$ Muslims as a sample. Data were collected using a five-point Likert scale questionnaire, then analyzed by multiple linear regression. The results showed that the influence of perception and purchasing decisions was positive, while religiosity and purchasing decisions had a negative effect. The results of this study indicate the decision to purchase skin care without a halal label can be determined based on how much a person's personal perception of the skin care product and religiosity related to spiritual values that influence one's actions in making decisions. Religiosity is very important in one's life. So, generation $Z$ who has a high level of religiosity will think of halal-haram for the actions they take during purchasing activities.
\end{abstract}

Umat Islam perlu mengkonsumsi barang halal, termasuk konsumsi produk skin care untuk perawatan wajah. Meskipun mayoritas penduduk Indonesia beragama Islam, tetapi tidak banyak produk yang sudah bersertifikat halal. Tujuan dari penelitian ini adalah untuk mengetahui faktor-faktor yang mempengaruhi keputusan pembelian skin care konsumen Muslim generasi $Z$ tanpa label halal di Banjarmasin. Penelitian ini adalah penelitian kuantitatif dengan 145 Muslim generasi Z Banjarmasin sebagai sampel. Data dikumpulkan dengan menggunakan kuesioner skala Likert lima poin, kemudian dianalisis dengan regresi linier berganda. Hasil penelitian menunjukkan bahwa pengaruh persepsi dan keputusan pembelian adalah positif, sedangkan religiusitas dan keputusan pembelian berpengaruh negatif. Hasil penelitian ini menunjukkan keputusan pembelian skin care tanpa label halal dapat ditentukan berdasarkan seberapa besar persepsi pribadi seseorang terhadap produk skin care tersebut dan religiusitas terkait dengan nilai-nilai spiritual yang mempengaruhi tindakan seseorang dalam mengambil keputusan. Religiusitas sangat penting dalam kehidupan seseorang. Sehingga generasi $\mathrm{Z}$ yang memiliki tingkat religiusitas tinggi akan memikirkan halal-haram untuk tindakan yang mereka lakukan selama kegiatan pembelian. 


\section{Pendahuluan}

Bagi kaum Muslim, Islam merupakan seperangkat aturan yang ditetapkan Allah untuk manusia yang sifatnya umum, baik berkenaan dengan ibadah maupun muamalah yang dipahami dari kandungan Alquran dan hadis sebagai pedoman hidup. Aturan yang disebut juga dengan syariat ini diyakini apabila dilaksanakan oleh umat Islam akan membawa kebahagiaan di dunia dan di akhirat. ${ }^{1}$ Salah satu perkara muamalah adalah konsumsi. Sebagaimana seorang Muslim bertanggungjawab mengenai hartanya (dari mana ia mendapatkan). Muslim juga bertanggungjawab terhadap dalam hal apa harta itu telah dibelanjakannya. Muslim tidak bebas untuk mendapatkan hartanya dari sesuatu yang haram, ia juga tidak bebas untuk membelanjakan hartanya dalam hal yang haram. Meski begitu, Islam memperbolehkan Muslim untuk menikmati berbagai karunia kehidupan dunia selama tidak melampaui batas. ${ }^{2}$

Batasan Islam tentang pembelanjaan memiliki dua kriteria yaitu pertama, batasan yang terkait dengan kuantitas dan ukurannya seperti terlalu kikir, pemborosan dan kemewahan yang berlebihan (Q.S. Al-Furqan/25: 67 dan Al-A'raf/7: 31); dan kedua, batasan yang terkait dengan kriteria sesuatu yang dibelanjakan seperti zat-zat yang dihalalkan dan diharamkan dalam Islam (Q.S. Al-Baqarah/2: 168, Al-Maidah/5: 88 dan An-Nahl/16: 80). ${ }^{3}$ Halal berarti barang tersebut tidak termasuk barang yang dilarang oleh Allah. Barang yang diharamkan Allah untuk dikonsumsi di antaranya adalah bangkai, darah, babi, dan hewan yang tidak disembelih tanpa menyebut nama Allah, yang tercekik, yang dipukul, yang terjatuh, yang ditanduk dan yang diterkam binatang buas, kecuali sempat untuk disembelih (Q.S. AlMaidah/5: 3). ${ }^{4}$

Mengingat kemajuan ilmu pengetahuan dan teknologi di bidang pangan, obat-obatan, dan kosmetik berkembang sangat pesat. Hal itu berpengaruh secara nyata pada pergeseran pengolahan dan pemanfaatan bahan baku untuk makanan, minuman, kosmetik, obat-obatan, serta produk lainnya dari yang semula bersifat sederhana dan alamiah menjadi pengolahan dan pemanfaatan bahan baku hasil rekayasa ilmu pengetahuan. Pengolahan produk dengan memanfaatkan kemajuan ilmu pengetahuan dan teknologi memungkinkan percampuran antara yang halal dan yang haram baik disengaja maupun tidak disengaja. Oleh karena itu, untuk mengetahui kehalalan dan kesucian suatu produk, diperlukan suatu kajian khusus yang membutuhkan pengetahuan multidisiplin, seperti pengetahuan di bidang pangan, kimia, biokimia, teknik industri, biologi, farmasi, dan pemahaman tentang syariat. Lembaga yang mempunyai wewenang untuk memberikan logo atau label halal pada suatu produk di Indonesia adalah Lembaga Pengkajian Pangan, Obat-obatan dan Kosmetika Majlis Ulama Indonesia (LPPOM MUI). ${ }^{5}$

Meskipun tidak dimakan, produk-produk skin care (perawatan kecantikan) juga merupakan bagian dari konsumsi yang memiliki aspek halal, haram dan najis. Kalau najis menempel di tubuh maka hal itu dapat mempengaruhi keabsahan ibadah yang dilakukan seorang Muslim

\footnotetext{
${ }^{1}$ Badri Khaeruman, Hukum Islam Dalam Perubahan Sosial (Bandung: Pustaka Setia, 2010). hlm. 11.

2 Yusuf Al Qardhawi, Peran Nilai Dan Moral Dalam Perekonomian Islam (Jakarta: Robbani Press, 2001). hlm. 235236.

${ }^{3}$ Al Qardhawi. hlm. 258-260

${ }^{4}$ Farokhah Muzayinatun Niswah, "Hubungan Persepsi Dan Religiusitas Terhadap Keputusan Pembelian Kosmetik Tanpa Label Halal," Jurnal Middle East and Islamic Studies 6, no. 1 (2018): 1-20. hlm. 2.

${ }^{5}$ Presiden Republik Indonesia, “Undang-Undang Republik Indonesia Nomor 33 Tahun 2014 Tentang Jaminan Produk Halal," Pub. L. No. 33 (2014).
} 
karena dalam persyaratan salat diharuskan suci badan, pakaian dan tempat dari najis. Maka tentu harus diperhatikan dengan cermat, jangan sampai menggunakan produk perawatan kecantikan yang ternyata mengandung zat haram dan najis. Apalagi kini, ketentuan tentang produk halal dan bebas dari najis telah ditetapkan secara legal-formal di dalam UndangUndang (UU) No 33 Tahun 2014 tentang Jaminan Produk Halal (JPH). ${ }^{6}$

Namun pada kenyataannya masih banyak produk skin care yang beredar dipasaran belum mendapatkan label halalnya. Penulis mendapatkan hanya sekitar 50 merek yang sudah memiliki sertifikat halal dari LPPOM MUI, sementara lainnya (umumnya merupakan produk luar negeri) belum bersertifikat halal. ${ }^{7}$ Banyaknya jumlah produk tanpa label halal yang beredar dan mayoritas penduduk Indonesia yang beragama Islam memberikan kemungkinan besar bahwa banyak konsumen Muslim mengonsumsi produk tanpa label halal. ${ }^{8}$

Konsumen yang semakin religius seharusnya akan semakin memperhatikan kehalalan suatu produk termasuk kosmetik seperti yang disimpulkan dalam penelitian Rosida, intensi konsumen dalam membeli skin care halal sebagian besar dipengaruhi oleh merek suatu produk, harga dan labelling (logo halal). ${ }^{9}$ Berseberangan dengan itu dalam penelitian Adiba dan Wulandari religiusitas dan pengetahuan halal pada konsumen generasi Y di Surabaya bukan menjadi pendorong dalam pembelian produk perawatan kecantikan berlabel halal. ${ }^{10}$ Menurut Amanu, variable sikap seperti memperhatikan nilai sebelum membeli produk skin care halal tidak diperhatikan dan justru sangat dipengaruhi oleh lingkungan sekitar. ${ }^{11}$ Menurut Niswah dalam penelitiannya pada 2018 lalu, tingginya jumlah produk perawatan kecantikan tanpa label halal yang beredar memengaruhi masyarakat dalam memutuskan untuk membeli kosmetik tersebut. ${ }^{12}$

Aspek-aspek dalam agama membuktikan bahwa nilai nilai tersebut dapat membentuk emosional individu, kesejahteran psilologi dan nantinya akan mampu memberikan pengaruh pada pilihan mereka dalam melakukan konsumsi. Firmansyah, Purnamasari dan Djakfar menemukan bahwa di Malang yang memiliki tingkat religiusitas tinggi akan memikirkan lingkungan atas tindakan yang dilakukannya selama melakukan kegiatan pembelian. ${ }^{13}$

\footnotetext{
6 LPPOM MUI, “Mengapa Kosmetika Harus Halal?," LPPOM MUI, 2017, http://www.halalmui.org/mui14/index.php/main/detil_page/138/23627.
}

7 LPPOM MUI Pusat, Daftar Belanja Produk Halal (Jakarta: LPPOM MUI Pusat, 2019), http://www.halalmui.org/mui14/images/daftarprodukhalal.pdf.

8 Niswah, "Hubungan Persepsi Dan Religiusitas Terhadap Keputusan Pembelian Kosmetik Tanpa Label Halal."

${ }^{9}$ Rida Rosida, "Faktor-Faktor Yang Mempengaruhi Intensi Pembelian Kosmetik Halal (Survey Pada Muslimah Di Jawa Barat)," Jurnal Ekonomi Dan Bisnis Islam (Journal of Islamic Economics and Business) 4, no. 2 (2018): 129-40, https://doi.org/10.20473/jebis.v4i2.10501.

${ }^{10}$ Elfira Maya Adiba and Dewi Ayu Wulandari, "Pengaruh Halal Knowledge, Islamic Religiosity, Dan Attitude Terhadap Behavior Konsumen Muslim Generasi Y Pengguna Kosmetik Halal Di Surabaya,” INOBIS: Jurnal Inovasi Bisnis Dan Manajemen Indonesia 1, no. 3 (2018): 357-69, https://doi.org/10.31842/jurnal-inobis.v1i3.42.

11 Ananda Abdillah Amanu, "Analisis Perilaku Pembelian Kosmetik Halal Berdasarkan Theory of Planned Behaviour (Studi Kasus Mahasiswa Perguruan Tinggi Agama Islam Swasta Yogyakarta),” UII Yogyakarta (Universitas Islam Indonesia, 2018).

12 Niswah, "Hubungan Persepsi Dan Religiusitas Terhadap Keputusan Pembelian Kosmetik Tanpa Label Halal."

13 Fani Firmansyah, Puji Endah Purnamasari, and Muhammad Djakfar, "Religiusitas, Lingkungan Dan Pembelian Green Product Pada Konsumen Generasi Z," IQTISHODUNA 15, no. 1 (2019): 57-70, https://doi.org/.1037//0033-2909.I26.1.78. 
Temuan Hashim dan Musa pada pemud-pemudi di Klang Valley menunjukkan bahwa kesadaran halal terhadap produk kecantikan rendah karena kehalalan bukanlah prioritas namun konten atau bahan dari produk adalah faktor paling penting yang dapat mempengaruhi mereka untuk mengkonsumsi suatu produk perawatan kecantikan. ${ }^{14}$

Indonesia adalah negara dengan mayoritas penduduk beragama Islam. Pada 2010 penduduk Indonesia yang beragama Islam mencapai $87.17 \%$ dari 239.89 juta jiwa total penduduk atau sekitar 209.12 juta jiwa. Bahkan pada 2020 diprediksi akan naik mencapai 263.92 juta jiwa dan pada 2050 menjadi 256.82 juta jiwa. ${ }^{15}$ Generasi Z sendiri adalah 30\% dari jumlah penduduk tersebut, terdiri dari pelajar dan mahasiswa. ${ }^{16}$ Hellen Katherina, Direktur Eksekutif, Kepala Bisnis Pengawasan, Nielsen Indonesia mengatakan bahwa karena generasi Z lahir di era digital, mereka memiliki kebiasaan yang sangat berbeda dari generasi sebelumnya, dan bahkan pada usia muda mereka sudah memiliki pengaruh yang cukup besar terhadap keputusan pembelian dalam keluarga. ${ }^{17}$

Penelitian-penelitian tersebut semakin memperkuat dugaan penulis bahwa masih banyak konsumen Muslim yang membeli skin care tanpa label halal. Terdapat beberapa penelitian yang sudah meneliti tentang keputusan pembelian terhadap kosmetik halal dan tanpa label halal oleh muslimah di Indonesia dan generasi $Y$, tetapi belum ditemui adanya penelitian yang tentang persepsi dan religiusitas terhadap keputusan pembelian skin care tanpa label halal pada generasi Z (tahun lahir 1995-2010) sehingga penelitian ini memiliki keterbaruan.

Penelitian ini akan menguji pengaruh persepsi dan religiusitas pada sikap pembentukan dan keputusan pembelian produk skin care tidak halal. Kajian ini bertujuan untuk mengetahui pengaruh dan hubungan antara persepsi dan religiusitas terhadap keputusan pembelian skin care oleh konsumen Muslim generasi Z di Banjarmasin.

\section{Landasan Teori}

Dalam Theory of planned behavior yang dikembangkan oleh Ajzen untuk memprediksi perilaku individu secara spesifik, kinerja individu dari perilaku tertentu ditentukan oleh niatnya untuk melakukan perilaku tersebut. ${ }^{18}$ Niat didefinisikan sebagai anteseden langsung perilaku. Ini menjelaskan bahwa sikap terhadap perilaku dan norma subyektif tentang keterlibatan dalam perilaku dianggap mempengaruhi niat pembelian skin care. Theory of planned behavior juga

\footnotetext{
${ }^{14}$ Azreen Jihan bt Che Mohd Hashim and Rosidah Musa, "Factors Influencing Attitude towards Halal Cosmetic among Young Adult Urban Muslim Women: A Focus Group Analysis," Procedia - Social and Behavioral Sciences 130 (2014): 129-34, https://doi.org/10.1016/j.sbspro.2014.04.016.

${ }^{15}$ pewforum.org, "Indonesia Religion: Demographics and Religion | PEW-GRF," Pew Research Center, 2019, http://www.globalreligiousfutures.org/countries/indonesia\#/?affiliations_religion_id=0\&affiliations_year=2 010\&region_name $=$ All Countries\&restrictions_year $=2016$.

16 Badan Pusat Statistik, Profil Generasi Milenial Indonesia (Jakarta: Kementrian Pemberdayaan Perempuan dan Perlindungan Anak, 2018), https://www.kemenpppa.go.id/lib/uploads/list/9acde-buku-profil-generasimilenia.pdf. hlm. 22.

17 Eliot Simangunsong, "Generation-Z Buying Behaviour in Indonesia: Opportunities for Retail Businesses," MIX: Jurnal Ilmiah Manajemen 8, no. 2 (2018): 243-53, https://www.researchgate.net/profile/Eliot_Simangunsong/publication/327247606_Generation-

Z_Buying_Behaviour_in_Indonesia_Opportunities_for_Retail_Businesses/links/5b890178a6fdcc5f8b73481

9/Generation-Z-Buying-Behaviour-in-Indonesia-Opportunities-for-Retail. hlm. 244.

18 Thomas J Madden, Pamela Scholder Ellen, and Icek Ajzen, “A Comparison of The Theory of Planned Behaviour and The Theory of Reasoned Action," Personality and Social Psychology Bulletin 18, no. 1 (1992): 3-9.
} 
mencakup kontrol perilaku yang dirasakan atas keterlibatan dalam perilaku sebagai faktor yang mempengaruhi niat dan perilaku pembelian. Sikap terhadap perilaku adalah evaluasi positif atau negatif dari melakukan perilaku tersebut dan kontrol perilaku yang dirasakan diinformasikan oleh keyakinan tentang kepemilikan peluang dan sumber daya yang dibutuhkan oleh individu untuk terlibat dalam perilaku. ${ }^{19}$

Theory of planned behavior mengaitkan perilaku manusia dengan keyakinan perilaku, yang mengarah pada sikap yang menguntungkan atau tidak menguntungkan terhadap perilaku; keyakinan normatif, yang mengarah pada tekanan sosial yang dirasakan atau norma subyektif; dan kontrol keyakinan, yang mengarah pada kontrol perilaku yang dirasakan. Ketiga faktor ini telah ditemukan secara signifikan mempengaruhi niat perilaku individu. Ini didasarkan pada asumsi bahwa manusia biasanya bertindak dengan perasaan. Maksudnya adalah bahwa manusia selalu mempertimbangkan segala hal baik dari luar maupun dalam, konsekuensi dan segala hal yang mempengaruhi atau dipengaruhi perilaku tersebut. Segala pertimbangan yang dilakukan manusia tersebut akhirnya akan membawa pada suatu bentuk niat (intention). Intention dapat menentukan dilakukannya atau tidak dilakukannya suatu aksi. ${ }^{20}$

Aksi seorang konsumen dalam membeli suatu produk dalam theory of consumer behavior disebutkan dipengaruhi oleh persepsi. ${ }^{21}$ Tahapan pemaparan, perhatian, dan pemahaman disebut sebagai persepsi. Persepsi ini bersama keterlibatan konsumen (level of consumer involvement) dan memori akan mempengaruhi pengolahan informasi. Setelah konsumen menyimpan informasi di dalam long-term memory, maka suatu saat ia akan memanggil kembali atau mengingat informasi tersebut untuk dipakai kembali sebagai pertimbangan dalam mengambil keputusan. Proses pengolahan informasi ini dipengaruhi oleh faktor pribadi dan faktor stimulus. Faktor pribadi adalah karakteristik konsumen yang muncul dari dalam diri konsumen. $^{22}$

Keputusan konsumen untuk menentukan pembelian sangat dipengaruhi oleh faktor kebudayaan, sosial, pribadi dan psikologi dari pembeli. Budaya adalah penentu keinginan dan perilaku seseorang yang paling mendasar. Budaya meliputi nilai-nilai dasar, persepsi, preferensi dan perilaku yang dipelajari seseorang dari keluarga dan institusi penting lainnya. Sosial juga mempengaruhi perilaku pembeli. Kelompok referensi seseorang seperti keluarga, teman-teman, organisasi sosial, asosiasi professional dapat memengaruhi pilihan produk. Sedang pribadi meliputi usia, tahap siklus hidup, pekerjaan, keadaan ekonomi, gaya hidup, kepribadian dan karakteristik pribadi lainnya dapat mempengaruhi keputusan pembelian seseorang. Faktor psikologi yang terdiri dari empat faktor psikologi utama, yaitu motivasi, persepsi, pembelajaran dan keyakinan serta sikap juga memengaruhi keputusan pembelian. ${ }^{23}$

Selain persepsi, agama juga dapat memengaruhi seseorang dalam memutuskan suatu pembelian barang atau jasa. Salah satu faktor yang memengaruhi perilaku pembelian

\footnotetext{
19 Indah Wahyuningsih, "Intensi Konsumen Terhadap Kosmetik Dan Produk Skincare Halal Di Indonesia: Pendekatan Theory of Planned Behavior," JEBA (Journal of Economics and Business Aseanomics) 3, no. 1 (2018): 41-59, https://doi.org/10.33476/jeba.v3i1.741. hlm. 44.

${ }^{20}$ Wahyuningsih. hlm. 45.

${ }^{21}$ Bobby J Calder and Robert E. Burnkrant, "Interpersonal Influence on Cosumer Behavior: An Attribution Theory Approach,” Journal of Consumer Research 4, no. 1 (1977): 29-38.

22 Ujang Sumarwan, Perilaku Konsumen: Teori Dan Penerapannya Dalam Pemasaran (Bogor: Ghalia Indonesia, 2011). hlm. 95 .

23 Sri Wigati, "Perilaku Konsumen Dalam Perspektif Ekonomi Islam,” Maliyah 01, no. 01 (2011): 22-39. hlm. 28-29.
} 
konsumen adalah faktor sosial yang terdapat unsur agama di dalamnya. Aktifitas beragama yang erat berkaitan dengan religiusitas, bukan hanya terjadi ketika melakukan ritual (ibadah) tetapi juga aktivitas lain yang didorong kekuatan batin. Tanggapan, pengamatan, pemikiran, perasaan dan sikap akan ketaatan yang diwarnai oleh rasa keagamaan disebut religiusitas. Religiusitas dapat dilihat dari aktivitas beragama dalam kehidupan sehari-hari yang dilaksanakan secara rutin dan konsisten. Agama merupakan fondasi terpenting dari budaya yang memengaruhi kebiasaan konsumen, sikap dan nilai. Agama berdampak pada kehidupan sehari- hari baik pada konsumsi maupun secara budaya. Komitmen agama dan kepercayaan memengaruhi perasaan dan sikap seseorang terhadap konsumsi. ${ }^{24}$

Konsumen Muslim yang ingin memperoleh manfaat dan keberkahan secara optimal akan melakukan tindakan yang rasional dalam melakukan kegiatan konsumsi. Rasionalitas seorang konsumen muslim berkaitan erat dengan kepribadiannya, seperti (1) Memiliki ketulusan sosial melalui sikap sabar, berempati terhadap sesama manusia, dan peka terhadap lingkungan; (2) Memiliki pikiran rasional melalui tindakan yang logis, terhitung, terukur, teranalisis dengan baik, dan melalui penalaran; dan (3) memiliki kebahagiaan melalui dekat dengan Allah, tenang jiwanya, puas jasmani, dan mencintai keindahan. ${ }^{25}$ Keinginan untuk mematuhi perintah dalam mengkonsumsi hanya produk halal dapat menciptakan keterlibatan dan pengaruh konsumen dalam membeli atau memilih produk apa yang mereka konsumsi.

Secara teoritis, paparan kepribadian konsumen Muslim mudah untuk dipahami. Namun ketika masuk kedalam wilayah praktis menjadi sulit karena setiap konsumen Muslim memiliki karakter dan persepsi yang berbeda. Mereka melihat aktivitas konsumsi dari cara pandang mereka masing-masing sehingga akan menimbulkan perbedaan persepsi. Perbedaan bisa mencakup, (1) persepsi konsumsi sesuai dengan kebutuhan, yaitu konsumsi yang mengutamakan kebutuhan dibandingkan keinginan, (2) persepsi menolak kemudharatan, yaitu menolak mengkonsumsi komoditas haram, mengabaikan kepentingan orang lain, dan membahayakan diri sendiri, (3) persepsi mardhatillah, yaitu sikap yang lebih mengutamakan aspek manfaat dibandingkan aspek kesenangan. Karena setiap konsumen muslim memiliki karakter dan persepsi yang berbeda maka hal ini akan mempengaruhi berbagai tindakannya seperti keputusan mengkonsumsi suatu komoditas. ${ }^{26}$

\section{Kerangka Konsep Penelitian}

Kerangka konsep dalam penelitian ini dapat digambarkan sebagai berikut:

\section{Gambar 1. Kerangka Konsep Penelitian}

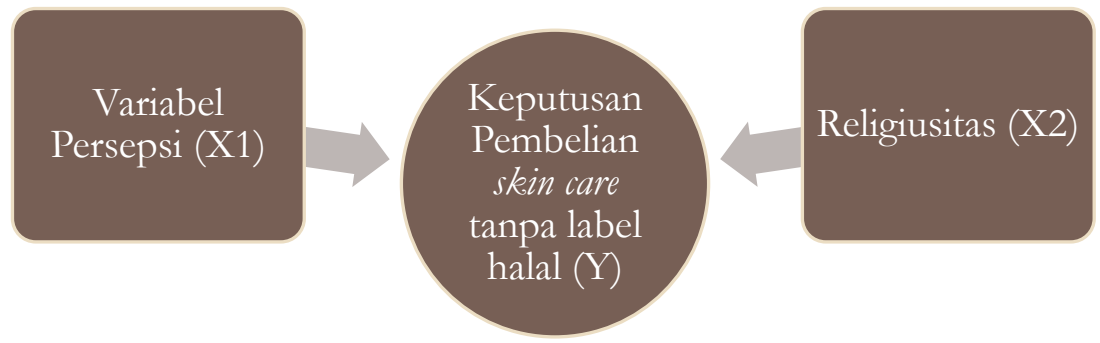

\footnotetext{
${ }^{24}$ Niswah, "Hubungan Persepsi Dan Religiusitas Terhadap Keputusan Pembelian Kosmetik Tanpa Label Halal." hlm. 5-6.

${ }_{25}$ Muhammad Muflih, Perilaku Konsumen Dalam Perspektif Ilmu Ekonomi Islam (Jakarta: Raja Grafindo Persada, 2006).

${ }^{26}$ Muflih. hlm. 96-97.
} 


\section{Hipotesis Penelitian}

$\mathrm{H}_{1}$ : Persepsi mempunyai pengaruh positif terhadap keputusan pembelian skin care tanpa label halal.

$\mathrm{H}_{2}$ : Religiusitas mempunyai pengaruh negatif terhadap keputusan pembelian skin care tanpa label halal.

\section{Metode Penelitian}

Sebagaimana tujuan dari penelitian ini yaitu untuk mengetahui pengaruh dan hubungan antara persepsi dan religiusitas terhadap keputusan pembelian skin care oleh konsumen Muslim generasi $Z$ di Banjarmasin maka variabel dalam penelitian ini adalah persepsi (X1), religiusitas (X2) dan keputusan pembelian skin care $(\mathrm{Y})$. Penelitian ini merupakan studi pada generasi Z (lahir pada tahun 1995-2010), mereka dianggap hal terbaik yang terjadi pada industri kecantikan selama bertahun-tahun. Menurut survei Per Piper Jaffrey, konsumsi untuk kecantikan naik 20 persen dari setahun yang lalu karena remaja terus berbelanja kosmetik dan perawatan kulit. ${ }^{27}$

Peneliti menggunakan kata skin care yang memiliki pengertian perawatan kulit atau serangkaian praktik yang mendukung integritas kulit, meningkatkan penampilan dan meringankan kondisi kulit yang mencakup nutrisi dan menghindari paparan sinar matahari yang berlebihan. ${ }^{28}$ Skin care penulis rasa lebih tepat untuk digunakan dibandingkan kata kosmetik karena skin care tidak memuat bias gender di mana generasi $\mathrm{Z}$ baik perempuan maupun laki-laki menggunakan skin care. Gen $Z$ peduli pada aturan-aturan modern yang mendukung pandangan yang lebih liberal tentang ras, jenis kelamin, identitas, seksualitas dan ekspresi diri, jadi tidak mengejutkan bahwa mereka berperan dalam tren kecantikan saat ini. Perempuan tidak lagi menjadi pasar produk kecantikan, pria muda juga telah masuk dalam industri ini. ${ }^{29}$

Penelitian ini menggunakan data kualitatif yang dikuantitatifkan dengan menggunakan Skala Likert untuk menguji pengaruh dan hubungan antara religiusitas dan persepsi terhadap keputusan pembelian skin care tanpa label halal. Penelitian ini menggunakan kuesioner guna mendapatkan data untuk membangun model penelitian berdasarkan wawasan yang diperoleh dari penelitian sebelumnya pada religiusitas dan persepsi berdasarkan teori perilaku konsumen dalam pembelian produk kosmetik seperti pada penelitian Niswah ${ }^{30}, \mathrm{Amanu}^{31}$,

27 Jeff Fromm, "The Influence of Identity: What Gen Z Wants from the Beauty Industry | Millennial Marketing," Millennial Marketing, 2018, http://www.millennialmarketing.com/2018/01/the-influence-ofidentity-what-gen-z-wants-from-the-beauty-industry/.

${ }^{28}$ Rebecca Penzer and Steven Ersser, Principles of Skin Care: A Guide for Nurses and Health Care Practitioners (Malaysia: John Wiley \& Sons, 2010).

${ }^{29}$ Jeff Fromm, "The Influence of Identity: What Gen Z Wants from the Beauty Industry | Millennial Marketing."

30 Niswah, "Hubungan Persepsi Dan Religiusitas Terhadap Keputusan Pembelian Kosmetik Tanpa Label Halal."

31 Amanu, "Analisis Perilaku Pembelian Kosmetik Halal Berdasarkan Theory of Planned Behaviour (Studi Kasus Mahasiswa Perguruan Tinggi Agama Islam Swasta Yogyakarta)." 
Musa $^{32}$, dan Fani ${ }^{33}$. Kuesioner diadopsi dengan beberapa modifikasi untuk mendapatkan informasi tentang keputusan pembelian skin care tanpa label halal pada generasi $\mathrm{Z}$ di Banjarmasin.

Skala Likert digunakan sebagai alat pengukuran variabel dengan menggunakan skala interval dalam bentuk checklist. Terdapat lima tingkatan jawaban dalam kuesioner, yaitu Sangat Tidak Setuju (1), Tidak Setuju (2), Netral (3), Setuju (4) dan Sangat Setuju (5). Setiap responden diminta untuk menunjukkan persetujuan atau ketidaksetujuannnya pada setiap pernyataan yang diajukan dalam kuesioner. Jumlah pertanyaan yang diajukan dalam kuesioner sebanyak 24 butir soal, yang terdiri dari 7 soal indikator variabel persepsi, 9 soal indikator variabel religiusitas dan 8 soal indikator variabel keputusan pembelian kosmetik tanpa label halal.

\section{Tabel 1. Tabel Variabel Operasional}

\begin{tabular}{|c|c|}
\hline Variabel & Indikator Pertanyaan \\
\hline \multirow{7}{*}{$\begin{array}{l}\text { Persepsi (X1) } \\
\text { ini adalah persepsi } \\
\text { konsumen muslim } \\
\text { yaitu pandangan } \\
\text { konsumen muslim } \\
\text { mengenai realitas } \\
\text { yang sifatnya } \\
\text { subjektif. }\end{array}$} & 1. Label halal pada skin care itu tidak penting bagi saya \\
\hline & $\begin{array}{l}\text { 2. Menurut saya tidak berdosa menggunakan skin care tanpa label } \\
\text { halal }\end{array}$ \\
\hline & 3. Produk tanpa label halal belum tentu haram \\
\hline & $\begin{array}{l}\text { 4. Skin care itu yang penting komposisinya tidak terkandung zat yang } \\
\text { dilarang agama (babi atau alkohol) }\end{array}$ \\
\hline & $\begin{array}{l}\text { 5. Skin care itu hanya untuk pemakaian luar sehingga tidak apa } \\
\text { menggunakan produk tanpa label halal }\end{array}$ \\
\hline & $\begin{array}{l}\text { 6. Banyak artis atau influenser Muslim yang menggunakan skin care } \\
\text { tersebut sehingga menurut saya tidak mengapa saya juga } \\
\text { menggunakannya }\end{array}$ \\
\hline & 7. Skin care itu yang penting sudah ada No. BPOM \\
\hline \multirow{9}{*}{$\begin{array}{l}\text { Religiustitas (X2) } \\
\text { adalah tingkat } \\
\text { religiusitas } \\
\text { responden dalam } \\
\text { kehidupan sehari- } \\
\text { hari. }\end{array}$} & 1. Saya percaya dengan 6 rukun iman \\
\hline & 2. Saya selalu berusaha menjalankan perintah agama \\
\hline & 3. Saya selalu berusaha menjauhi larangan agama \\
\hline & 4. Saya mengerjakan sholat 5 waktu setiap hari \\
\hline & $\begin{array}{l}\text { 5. Saya selalu berpuasa pada bulan Ramadhan (kecuali dalam keadaan } \\
\text { yang diperbolehkan meninggalkannya) }\end{array}$ \\
\hline & 6. Saya selalu membayar zakat fitrah setiap tahun \\
\hline & 7. Saya akan melaksanakan haji jika mampu \\
\hline & 8. Saya rutin membaca Alquran \\
\hline & 9. Saya berusaha rutin mengerjakan perkara sunah \\
\hline
\end{tabular}

\footnotetext{
32 Hashim and Musa, "Factors Influencing Attitude towards Halal Cosmetic among Young Adult Urban Muslim Women: A Focus Group Analysis."

33 Firmansyah, Purnamasari, and Djakfar, "Religiusitas, Lingkungan Dan Pembelian Green Product Pada Konsumen Generasi Z.”
} 
Keputusan

Pembelian skin care tanpa label halal (Y)
1. Saya tidak memperhatikan ada/ tidaknya label halal pada skin care sebelum membeli

2. Saya lebih memperhatikan merek ketimbang label halal pada skin care

3. Saya tidak ragu membeli skin care tanpa label halal

4. Saya lebih memilih skin care yang direkomendasikan oleh idola, artis, beauty vlogger/blogger yang saya ikuti

5. Saya membeli skin care yang dipakai teman atau saudara saya

6. Saya tetap membeli skin care tanpa label halal meskipun tahu ada kosmetik berlabel halal

7. Saya lebih memilih skin care secara online karena mudah bagi saya

8. Saya lebih memilih skin care dengan harga yang terjangkau

Persamaan regresi berganda: $Y=\alpha+\beta 1 X 1+\beta 2 X 2+e$.

Dimana:

$$
\begin{aligned}
& \mathrm{Y}=\text { Keputusan Pembelian skin care tanpa label halal } \\
& \alpha=\text { nilai konstanta dalam regresi }
\end{aligned}
$$

$\beta 1$ dan $\beta 2=$ nilai koefisien regresi

$$
\mathrm{e}=\text { error. }
$$

Metode pengumpulan data yang digunakan adalah metode pengumpulan data primer dan sekunder. Data primer didapatkan melalui penyebaran kuesioner. Kuesioner dibuat secara online melalui Google form dan disebarkan melalui beberapa media sosial, seperti Line, Whatsapp, Instagram, Facebook dan Twitter. Teknik pengambilan sampel menggunakan purposive random sampling. Kriteria sampel dalam penelitian ini adalah generasi Z Banjarmasin yang beragama Islam dan menggunakan produk skin care. Sedangkan data sekunder diperoleh dari buku dan literatur yang berkaitan dengan topik permasalahan yang dibahas.

Data yang dikumpulkan berupa data kuesioner, sehingga sebelum dilakukan analisis, data harus melewati uji reliabilitas dan uji validitas. Dinyatakan valid jika $r$-tabel $<$ r-hitung dan tidak valid jika r-tabel $>$ r-hitung. Sedangkan uji reliabilitas mengindikasikan stabilitas dan konsistensi, suatu kuesioner dikatakan reliabel atau handal jika jawaban seseorang terhadap pernyataan adalah konsisten atau stabil dari waktu ke waktu. Hipotesis dalam penelitian ini, yaitu: $\mathrm{H}_{1}$ : Persepsi mempunyai pengaruh positif terhadap keputusan pembelian skin care tanpa label halal. $\mathrm{H}_{2}$ : Religiusitas mempunyai pengaruh negatif terhadap keputusan pembelian skin care tanpa label halal. Untuk dapat menjawab hipotesis, metode analisis data yang digunakan dalam penelitian ini adalah analisis regresi linier berganda (Multiple Linier Regression Analysis). Analisis ini digunakan untuk mencari hubungan antara persepsi dan religiusitas terhadap keputusan pembelian kosmetik tanpa label halal baik secara individu maupun secara bersamasama. Analisis regresi linier berganda mensyaratkan untuk dilakukan uji asumsi klasik agar mendapatkan hasil regresi yang baik. Uji asumsi klasik terdiri dari uji normalitas, uji multikolinieritas dan heteroskedastisitas. ${ }^{34}$

\footnotetext{
${ }^{34}$ Suharyadi and Purwanto S.K., Statistika Untuk Ekonomi Dan Kenangan Modern Buku 2, 3rd ed. (Jakarta: Salemba Empat, 2017). hlm. 223-257.
} 


\section{Pembahasan}

Demografi responden dalam penelitian ini disusun berdasarkan usia dan gender. Uji statistic descriptive dilakukan untuk mempermudah mengetahui demografi responden. Responden dalam penelitian ini berjumlah 145 orang yang didominasi oleh perempuan sebanyak 99 orang atau $68 \%$ dan laki-laki sebanyak 46 orang atau 32\%. Responden termuda adalah kelahiran 2004 yang tahun ini berumur 15 tahun, sedangkan responden terbanyak adalah pada kisaran umur 20-21 tahun yang lahir pada tahun 1997-1998 yakni sebanyak 27.58\% dari total responden atau berjumlah 40 orang.

Data dilakukan uji validitas dan reliabilitas sebelum data dianalisis. Semua variabel penelitian dinyatakan lulus uji validitas dengan $\mathrm{r}_{\text {hitung }}>\mathrm{r}_{\text {tabel. }} .{ }^{35}$ Metode yang digunakan untuk uji validitas adalah uji korelasi pearson. Uji validitas dapat ditunjukan pada tabel berikut:

Tabel 2. Hasil Uji Validitas

\begin{tabular}{|c|c|c|c|}
\hline Variabel & $\mathbf{r}_{\text {hitung }}$ & $\mathbf{r}_{\text {tabel }}$ & Keterangan \\
\hline \multicolumn{4}{|l|}{ Persepsi } \\
\hline $\mathrm{X}_{11}$ & 8.9356 & 1.6556 & valid \\
\hline $\mathrm{X}_{12}$ & 12.3011 & 1.6556 & valid \\
\hline $\mathrm{X}_{13}$ & 11.1643 & 1.6556 & valid \\
\hline $\mathrm{X}_{14}$ & 6.9191 & 1.6556 & valid \\
\hline $\mathrm{X}_{15}$ & 14.6952 & 1.6556 & valid \\
\hline $\mathrm{X}_{16}$ & 11.5478 & 1.6556 & valid \\
\hline $\mathrm{X}_{17}$ & 8.3528 & 1.6556 & valid \\
\hline \multicolumn{4}{|c|}{ Religusitas } \\
\hline $\mathrm{X}_{21}$ & 2.9069 & 1.6556 & valid \\
\hline $\mathrm{X}_{22}$ & 2.9069 & 1.6556 & valid \\
\hline $\mathrm{X}_{23}$ & 11.6069 & 1.6556 & valid \\
\hline $\mathrm{X}_{24}$ & 8.5420 & 1.6556 & valid \\
\hline $\mathrm{X}_{25}$ & 12.1242 & 1.6556 & valid \\
\hline $\mathrm{X}_{26}$ & 6.1705 & 1.6556 & valid \\
\hline $\mathrm{X}_{27}$ & 7.6086 & 1.6556 & valid \\
\hline $\mathrm{X}_{28}$ & 3.9465 & 1.6556 & valid \\
\hline $\mathrm{X}_{29}$ & 12.0331 & 1.6556 & valid \\
\hline \multicolumn{4}{|c|}{$\begin{array}{c}\text { Keputusan pembelian skin care tanpa label } \\
\text { halal }\end{array}$} \\
\hline $\mathrm{Y}_{11}$ & 10.259 & 1.6556 & valid \\
\hline$Y_{12}$ & 15.879 & 1.6556 & valid \\
\hline
\end{tabular}

35 Suharyadi and S.K. hlm. 244-276. 


\begin{tabular}{ccccc}
\hline $\mathrm{Y}_{13}$ & 15.761 & 1.6556 & valid \\
\hline $\mathrm{Y}_{14}$ & 12.556 & 1.6556 & valid \\
\hline $\mathrm{Y}_{15}$ & 11.008 & 1.6556 & valid \\
\hline $\mathrm{Y}_{16}$ & 15.427 & 1.6556 & valid \\
\hline $\mathrm{Y}_{17}$ & 8.7871 & 1.6556 & valid \\
\hline $\mathrm{Y}_{18}$ & 6.1735 & 1.6556 & valid \\
\hline
\end{tabular}

Uji reliabilitas bertujuan untuk mengetahui mengetahui tingkat konsistensi jawab kuesioner, sehingga menunjukan keadalan dalam sebuah alat ukur. Dalam pengujian di lakukan dengan uji Cronbach's Alpha. Jika alpha $>0.90$ maka reliabilitas sempurna. Jika alpha antara $0.70-$ 0.90 maka reliabilitas tinggi. Jika alpha $0.50-0.70$ maka reliabilitas moderat. Jika alpha $<0.50$ maka reliabilitas rendah. Jika alpha rendah, kemungkinan satu atau beberapa item tidak reliabel. ${ }^{36}$ Hasil uji reliabilitas ditunjukkan sebagai berikut:

Tabel 3. Hasil Uji Reabilitas

\begin{tabular}{lcc}
\hline Variabel & $\begin{array}{c}\text { Cornbach's } \\
\text { Alpha }\end{array}$ & $\begin{array}{c}\text { Keterangan } \\
\text { Reabilitas }\end{array}$ \\
\hline Persepsi & 0.5976 & Moderat \\
\hline Religiousitas & 0.5884 & Moderat \\
\hline Keputusan pembelian skin care tanpa label halal & 0.8393 & Tinggi \\
\hline
\end{tabular}

\section{Analisis Regresi Berganda}

Analisis regresi berganda bertujuan mengetahui ada atau tidaknya pengaruh dua variabel atau lebih $(\mathrm{X})$ terhadap variabel terikat $(\mathrm{Y})$. Analisis regresi berganda digunakan apabila variabel bebas (independen) lebih dari satu. Namun sebelum dilakukan uji regresi, dilakukan uji asumsi klasik terlebih dahulu. Data dalam penelitian ini dinyatakan telah memenuhi ketiga uji asumsi klasik yang terdiri dari uji normalitas, uji multikolinearitas dan uji heteroskedastisitas. Data telah berdistribusi normal karena diperoleh nilai signifikansi dari uji KolmogorovSmirnov lebih dari 0.05 atau sebesar 0.102212. Pada uji parsial, didapatkan $r_{y \times 1}=0.671, r_{y \times 2}$ $=-0.299$, dan $\mathrm{r}_{\mathrm{yx} 1 \times 2}=0.142$. Nilai koefisien parsial tersebut lebih kecil dari $\mathrm{R}=0.678$ sehingga dapat disimpulkan tidak terjadi multikolinier. Kedua variabel bebas tersebut juga dinyatakan telah memenuhi asumsi heteroskedastisitas dengan nilai signifikansi persepsi $\left(\mathrm{X}_{1}\right)$ pada uji Glejser lebih dari 0.05 atau sebesar 0,737 dan religiusitas $\left(\mathrm{X}_{2}\right)$ sebesar 0.835 .

Tabel 4. Hasil Uji Asumsi Klasik

\begin{tabular}{lcl}
\hline Hasil & Nilai & \multicolumn{1}{c}{ Keterangan } \\
\hline Asymp. Sig. (2-tailed) & 0.102212 & $>0.05$, Distribusi Normal \\
\hline Koefisien korelasi parsial YX1 & 0.671 & $<\mathrm{R}$, bebas multikolinieritas \\
\hline Koefisien korelasi parsial YX2 & -0.299 & $<\mathrm{R}$, bebas multikolinieritas \\
\hline
\end{tabular}

${ }^{36}$ Suharyadi and S.K. hlm. 244-276. 


\begin{tabular}{lcl}
\hline $\begin{array}{l}\text { Koefisien korelasi parsial } \\
\text { YX1X2 }\end{array}$ & 0.594 & $<\mathrm{R}$, bebas multikolinieritas \\
\hline Sig. (Dep. Var. Abs) X1 & 0.737 & $>0.05$, memenuhi heteroskedastisitas \\
\hline Sig. (Dep. Var. Abs) X2 & 0.835 & $>0.05$, memenuhi heteroskedastisitas \\
\hline
\end{tabular}

Gambar 2. Grafik Normalitas Data

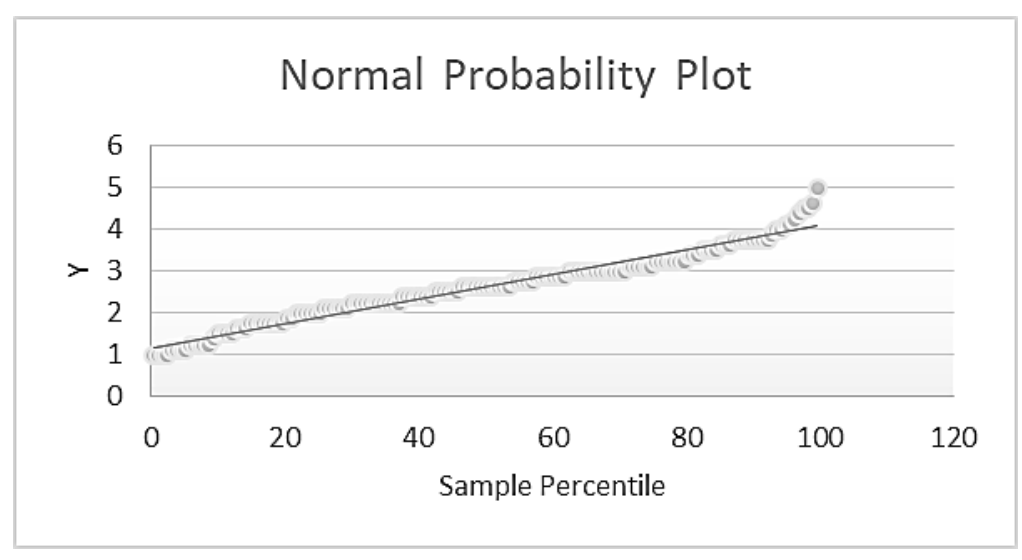

Jika data menyebar disekitar garis diagonal dan mengikuti arah garis diagonal, maka model regresi memenuhi asumsi normalitas. Grafik di atas menunjukan bahwa data menyebar disekitar garis diagonal dan mengikuti arah garis diagonal, dapat disimpulkan bahwa model regresi memenuhi asumsi normalitas. ${ }^{37}$

Data telah lolos uji asumsi klasik sehingga dapat dilakukan analisis regresi linier berganda untuk menjawab hipotesis yang diajukan dalam penelitian ini yang penulis rangkum sebagai berikut.

Tabel 5. Hasil Uji Regresi Linier Berganda

\begin{tabular}{ll}
\hline \multicolumn{1}{c}{ Hasil } & Nilai \\
\hline $\mathrm{R}$ & 0.678335 \\
\hline R square & 0.460138 \\
\hline F hitung & 60.51507 \\
\hline Sig. (ANOVA) & 0.000000 \\
\hline Koefisien konstanta & 1.690148 \\
\hline Koefisien Persepsi $\left(\mathrm{X}_{1}\right)$ & 0.703002 \\
\hline Koefisien Religiusitas $\left(\mathrm{X}_{2}\right)$ & -0.2488 \\
\hline P-Value Persepsi $\left(\mathrm{X}_{1}\right)$ & 0.0000 \\
\hline P-Value Religiusitas $\left(\mathrm{X}_{2}\right)$ & 0.1106 \\
\hline
\end{tabular}

${ }^{37}$ Suharyadi and S.K. hlm. 319. 
Berdasarkan hasil output didapatkan angka $\mathrm{R}$ sebesar 0.678 yang menunjukkan bahwa korelasi atau hubungan antara keputusan pembelian skin care tidak halal dengan dua variabel independen nya kuat. Dinyatakan kuat karena angka R lebih dari 0.5. Angka R square atau koefisien determinasi sebesar 0.460138 yang berarti $46.01 \%$ variasi dari keputusan pembelian kosmetik tanpa label halal bisa dijelaskan oleh variasi dari kedua variabel independen persepsi dan religiusitas. Sedangkan sisanya 53.98\% dijelaskan oleh variabel lain yang tidak diteliti dalam penelitian ini.

Berdasarkan uji Anova atau F test yang dilakukan, didapatkan F hitung 60.51507 dengan tingkat signifikansi 0.000. Karena nilai signifikansi 0.000 lebih kecil dari 0.05 , maka model regresi bisa dipakai untuk memprediksi keputusan pembelian kosmetik tanpa label halal, atau bisa dikatakan persepsi dan religiusitas secara bersama-sama berpengaruh terhadap keputusan pembelian kosmetik tanpa label halal. Model regresi yang didapatkan dalam penelitian ini adalah: Keputusan pembelian skin care tanpa label halal $=1.169+0.703$ Persepsi -0.2488 Religiusitas.

Konstanta 1.169 menyatakan bahwa jika tidak terdapat persepsi dan religiusitas, maka keputusan pembelian sebesar 1.169 unit. Koefisien regresi 0.703 menyatakan bahwa setiap penambahan 1-unit persepsi akan meningkatkan keputusan pembelian sebesar 0.703 unit. Koefisien regresi -0.2488 menyatakan bahwa setiap penambahan 1-unit religiusitas akan menurunkan keputusan pembelian sebesar 0.2488 unit.

Berdasarkan hasil regresi yang dilakukan, persepsi mempunyai pengaruh secara signifikan terhadap keputusan pembelian kosmetik tanpa label halal dengan ditunjukkan oleh nilai signifikansi uji t kurang dari 0.05 yaitu sebesar 0.000. Ini menunjukkan bahwa H0 ditolak dan $\mathrm{H}_{1}$ diterima. Persepsi dan keputusan pembelian kosmetik tanpa label halal memiliki hubungan positif yang signifikan. Artinya semakin tinggi persepsi seseorang terhadap suatu kosmetik tanpa label halal, maka semakin tinggi pula orang tersebut memutuskan untuk membeli produk kosmetik tanpa label halal.

Hal tersebut dipengaruhi oleh faktor psikologis yang utama dalam keputusan niat beli konsumen yaitu motivasi dan persepsi, proses belajar, serta kepercayaan dan sikap. ${ }^{38}$ Ini sejalan dengan Teori Motivasi Maslow yang mencoba menjelaskan mengapa seseorang yang termotivasi akan siap bereaksi. Menurutnya bagaimana orang itu bertindak dipengaruhi oleh persepsi mengenai situasi. Dua orang dalam kondisi motivasi yang sama dan tujuan situasi yang sama mungkin bertindak secara berbeda karena perbedaan persepsi mereka terhadap situasi itu. Persepsi menurut Philip Kotler diartikan sebagai proses di mana individu memilih, merumuskan, dan menafsirkan masukan informasi untuk menciptakan suatu gambaran yang berarti mengenai dunia. ${ }^{39}$

Persepsi merupakan salah satu faktor yang dapat memepengaruhi seseorang memutuskan untuk melakukan suatu pembelian barang atau jasa. Orang dapat memberikan persepsi yang berbeda terhadap rangsangan yang sama karena tiga proses persepsi dibawah ini:

1. Perhatian yang selektif. Orang pada umumnya dihadapkan pada jumlah rangsangan yang sangat banyak setiap hari dan tidak semua rangsangan ini dapat diterima. Perhatian yang selektif berarti harus dapat menarik perhatian konsumen, di mana pesan yang disampaikan akan hilang bagi kebanyakan orang yang tidak berada dalam pasar untuk produk tersebut,

\footnotetext{
38 Wigati, "Perilaku Konsumen Dalam Perspektif Ekonomi Islam.” hlm. 29

${ }^{39}$ Bilson Simamora, Panduan Riset Perilaku Konsumen (Jakarta: Gramedia Pustaka Utama, 2008). hlm. 12.
} 
kecuali untuk pesan yang cukup menonjol atau dominan yang mengelilingi konsumen pasar tersebut. ${ }^{40}$

2. Gangguan yang selektif. Rangsangan yang diperhatikan konsumen pun tidak selalu seperti apa yang dimaksud. Setiap orang berusaha menyesuaikan informasi yang masuk dengan pandangannya. Distorsi selektif menggambarkan kecenderungan orang untuk meramu informasi kedalam pengertian pribadi. Orang cenderung menafsirkan informasi dengan cara yang lebih mendukung daripada menentang konsepsi-konsepsi yang telah dimilikinya. ${ }^{41}$

3. Mengingat kembali yang selektif. Orang cenderung melupakan apa yang mereka pelajari dan menahan informasi yang mendukung sikap dan kepercayaan mereka. Mengingat yang selektif berarti mereka akan mengingat apa yang dikatakan sebagai keunggulan suatu produk dan melupakan komponen yang dianggap tidak penting. ${ }^{42}$

Pengaruh persepsi ini terlihat dari $15.17 \%$ responden generasi $\mathrm{Z}$ di Banjarmasin mengaku setuju dan $50 \%$ mengaku sangat setuju bahwa yang paling penting dari skin care adalah sudah ada sertifikat dari BPOM sedangkan yang tidak setuju hanya berjumlah 6\% dari total responden. Stimuli yang berasal dari sumber yang dipercaya dan dihormati akan sering memberikan bobot persepsi yang lebih tinggi. Ini artinya generasi $\mathrm{Z}$ di Banjarmasin meyakini bahwa skin care yang telah lulus uji BPOM akan aman mereka pakai dan inilah yang terpenting.

51\% generasi Z Banjarmasin menyatakan sangat setuju dan 23.5\% setuju jika yang terpenting dari skin care ialah komposisinya tidak terkandung zat yang dilarang agama (babi atau alkohol). Distorsi selektif yang generasi $\mathrm{Z}$ miliki mengenai informasi halal-haram suatu zat membuat mereka cenderung mengolah informasi sesuai dengan pengertian pribadi yang membuat mereka loncat pada suatu kesimpulan dari tafsiran mereka sendiri.

Ini diperkuat pula oleh Hashim dan Musa dalam penelitian mereka, yakni label halal bukanlah faktor utama bagi pemudi di Klang Valley dalam mengkonsumsi suatu produk kecantikan. Kandungan atau bahan produk merupakan faktor terpenting yang lebih mereka pertimbangkan dalam membuat keputusan pembelian. Mereka terlebih dahulu akan melihat kemasan produk untuk mengetahui informasi isi atau bahan yang terkandung dalam produk tersebut sebelum membeli. Jika produk tersebut berasal dari bahan alami dan tidak terdapat keraguan pada komposisi yang tercantum (tidak mengandung babi, alkohol, plasenta, janin, lemak hewani atau organ), maka mereka merasa sudah cukup. Informasi yang didapatkan konsumen dari kemasan tersebut akan mempengaruhi seseorang dalam membuat keputusan pembelian terhadap suatu produk skin care. ${ }^{43}$

Merasa sudah cukup dengan melihat komposisi suatu produk skin care ini diamini oleh 40.7\% generasi $Z$ Banjarmasin yang setuju dan sangat setuju dengan pernyataan bahwa produk yang tidak berlabel halal belum tentu haram. $16.5 \%$ dari generasi $\mathrm{Z}$ tersebut setuju dan sangat setuju bahwa mereka tidak akan berdosa jika memakai skin care tanpa label halal, sedangkan mayoritas 38\% menyatakan netral mengenai hukum nya. Meski begitu hanya $12.5 \%$ yang

\footnotetext{
40 Simamora. hlm. 12

${ }^{41}$ Simamora. hlm. 13

42 Simamora. hlm. 13.

${ }^{43}$ Hashim and Musa, "Factors Influencing Attitude towards Halal Cosmetic among Young Adult Urban Muslim Women: A Focus Group Analysis."
} 
menyetujui alasan skin care hanyalah untuk pemakaian luar sehingga tidak mengapa menggunakan produk skin care tanpa label halal.

Kecenderungan menggunakan persepsi ini dijelaskan pula oleh penelitian Amanu yang berkesimpulan bahwa terdapat pengaruh yang signifikan terhadap variabel niat (intention) untuk membeli produk kecantikan halal. Ini artinya responden cenderung membeli suatu produk kecantikan halal dipengaruhi oleh lingkungan sekitar. Lingkungan sekitar dalam hal ini yaitu pengaruh teman terdekat, keluarga, dan tempat sekitar yang akan memberikan informasi yang akan menjadi persepsi bagi konsumen. ${ }^{44}$ Ini juga berkesesuaian dengan theory of Planned Behaviour yang menyatakan bahwa keputusan yang dibuat oleh seseorang ialah atas dasar persepsi atau penilaian mereka sendiri dan atas dasar pertimbangan orang lain yang dianggap penting.

Responden generasi Y dalam penelitian yang dilakukan oleh Adiba dan Wulandari juga tidak mempertimbangkan aspek halal terhadap produk kecantikan yang dibeli. Menurut Adiba produk kecantikan luar negeri yang semakin marak beredar di Indonesia membuat generasi Y di Surabaya tidak ketinggalan untuk memakainya. Misalnya kosmetik dari Korea Selatan juga semakin meningkat, terlihat dari beberapa situs e-commerce yang sering mengalami kehabisan produk dari negera tersebut. Hal ini juga dipengaruhi oleh ulasan dari beauty blogger, iklan selebriti, dan tayangan seperti film atau drama dimana para aktor atau aktrisnya sedang menggunakan produk kecantikan tersebut dalam beberapa adegan. Berkembangnya produkproduk dari luar negeri juga terlihat dari pertumbuhan jumlah outlet skin care yang tidak hanya di ibukota, tetapi juga sudah merambah di kota-kota besar di Indonesia. Beberapa produk luar negeri tersebut belum mendapat sertifikasi halal dari LPPOM MUI. ${ }^{45}$

Generasi Z Banjarmasin juga mengalami hal yang serupa. Sebanyak 18.62\% responden generasi $\mathrm{Z}$ menyatakan setuju dan sangat setuju membeli skin care secara online karena lebih mudah bagi mereka, sedangkan $26.20 \%$ netral dalam hal ini. Tumbuh di era media sosial dan selfie, generasi $Z$ lebih terobsesi pada penampilan mereka daripada generasi sebelumnya. Tentu, kedengarannya agak narsis, tetapi alasannya lebih kompleks dari yang diperkirakan. Remaja zaman ini tahu mereka dapat difoto kapan saja, di mana saja, dan mereka berharap gambar-gambar itu akan berakhir indah pada jejarang sosial online. Remaja memandang identitas pribadi mereka sebagai komposisi yang dikuratori; mereka membangun labelpribadi' mereka sendiri seiring waktu. Membangun jati diri ini dimulai pada usia muda dan terus berkembang. Dengan identitas pribadi yang diurus dengan hati-hati sehingga dipublikasikan di media sosial, mereka sangat sadar akan cara mereka menampilkan diri. ${ }^{46}$

Dalam pencarian berkelanjutan mereka untuk mendefinisikan jati diri, remaja bersenangsenang dengan bereksperimen melalui kepribadian mereka, kecantikan, gaya rambut dan mode. Generasi Z berbagi proses itu dengan teman-teman mereka (baik online maupun offline). Alih-alih beralih ke ibu atau saudara mereka yang lebih tua untuk mendapatkan nasihat kecantikan, para remaja memilih online untuk ide, tren, dan tutorial langkah demi langkah dari beberapa influencer favorit di jejaring sosial mereka. ${ }^{47}$ Dapat dilihat dari $20.7 \%$

\footnotetext{
44 Amanu, "Analisis Perilaku Pembelian Kosmetik Halal Berdasarkan Theory of Planned Behaviour (Studi Kasus Mahasiswa Perguruan Tinggi Agama Islam Swasta Yogyakarta).”

45 Adiba and Wulandari, "Pengaruh Halal Knowledge, Islamic Religiosity, Dan Attitude Terhadap Behavior Konsumen Muslim Generasi Y Pengguna Kosmetik Halal Di Surabaya."

46 Jeff Fromm, "The Influence of Identity: What Gen Z Wants from the Beauty Industry | Millennial Marketing."

${ }^{47}$ Jeff Fromm.
} 
responden generasi $Z$ Banjarmasin setuju dan sangat setuju bahwa mereka lebih memilih skin care yang direkomendasikan oleh idola, artis, beauty vlogger dan blogger yang mereka ikuti, sedang $30.7 \%$ nya menyatakan netral. Dapat dipahami bahwa generasi $Z$ ini adalah generasi yang lahir dalam era teknologi informasi. Oleh karena itu mindset dari generasi ini adalah mindset teknologis dan cenderung positifistik, sehingga mereka lebih mudah mempercayai realitas dengan ukuran-ukuran objektif, empirik, dan rasional. Dengan kondisi semacam itu informasi dan persepsi yang mereka miliki kemudian menjadi realitas yang memengaruhi keputusan mereka dalam pembelian skin care.

Berdasarkan hasil regresi juga dapat diketahui bahwa religiusitas tidak berpengaruh secara signifikan terhadap keputusan pembelian skin care tanpa label halal karena nilai signifikansi lebih dari 0.05 yaitu 0.1106. Religiusitas dan keputusan pembelian skin care tanpa label halal memiliki hubungan negatif. Semakin tinggi religiusitas seseorang, maka semakin rendah orang tersebut memutuskan untuk membeli skin care tanpa label halal. Orang yang memiliki religiusitas tinggi akan lebih memilih produk halal, termasuk dalam hal pembelian produk skin care karena Islam telah memerintahkan umatnya untuk mengonsumsi barang yang halal. Semakin tinggi tingkat religiusitas seseorang, semakin tinggi intensi untuk membeli produk berlabel halal. Sedangkan kehalalan suatu produk hanya dapat dipastikan melalui label halal yang tertera pada kemasan produk. ${ }^{48}$

Penelitian Niswah mendukung temuan ini, ia menjelaskan orang yang taat pada agamanya akan lebih berhati-hati dalam membeli suatu produk, karena mereka menyakini segala sesuatu yang dibeli akan berdampak pada kekhusyukan ibadah kepada Allah. Meskipun akibat yang ditimbulkan tidak terlalu berdampak terhadap fisik namun berdampak pada spiritual manusia tersebut. Tujuan konsumsi Islami adalah maslahah, yaitu terpenuhinya kebutuhan fisik maupun kebutuhan spiritual. Sehingga yang ingin dicapai bukan hanya kepuasan duniawi tetapi juga untuk kesejahteraan di akhirat. Muslim mengakui bahwa konsumsi juga harus bernilai ibadah. $^{49}$

Tetapi penelitian ini tidak sejalan dengan Adiba dan Wulandari yang mengamati generasi Y Surabaya. Konsumen yang semakin religius seharusnya akan semakin memperhatikan kehalalan suatu produk termasuk kosmetik, namun dalam penelitian Adiba dan Wulandari religiusitas konsumen generasi Y di Surabaya bukan menjadi pendorong dalam pembelian produk skin care. Hal ini disebabkan adanya kecenderungan generasi Y menggunakan merk tertentu untuk mempertahankan dan menguatkan jati diri mereka, sehingga religiusitas tidak menjadi alasan mereka dalam pembelian skin care. Alasannya menurut Adiba dan Wulandari karena generasi $Y$ di Surabayan merupakan generasi yang reaktif dan sangat tanggap dengan informasi dari internet, sehingga apa yang mereka lihat dan dijadikan panutan adalah orangorang yang mengisi konten media sosial di dunia maya. Hal ini menyebabkan perilaku dalam pembelian barang tidak didominasi oleh tingkat religiusitas ${ }^{50}$

Tentu saja perbedaan ini didorong oleh perbedaan wilayah penelitian. Banjarmasin, yang semula merupakan suatu perkampungan orang Melayu, menjadi pelabuhan yang disinggahi oleh para pedagang Muslim, menjadi kota Muslim, dan berlanjut menjadi kota kerajaan. Sultan dan masyarakatnya mengembangkan agama Islam, sehingga Islam di Banjarmasin

\footnotetext{
48 Niswah, "Hubungan Persepsi Dan Religiusitas Terhadap Keputusan Pembelian Kosmetik Tanpa Label Halal." hlm. 16.

${ }^{49}$ Niswah. hlm 17.

50 Adiba and Wulandari, "Pengaruh Halal Knowledge, Islamic Religiosity, Dan Attitude Terhadap Behavior Konsumen Muslim Generasi Y Pengguna Kosmetik Halal Di Surabaya.” hlm. 366.
} 
mengalami perkembangan yang cukup menyeluruh di segala bidang, baik dalam bidang politik, ekonomi, dan sosial maupun budaya. Semuanya itu telah melahirkan suatu peradaban Islam yang khas di Banjarmasin, dimana agama Islam cukup berkembang pesat di Kalimantan khususnya. ${ }^{51}$

Meskipun generasi $\mathrm{Z}$ adalah anak muda yang kehidupan sosialnya jauh berbeda dengan generasi-generasi sebelumnya, namun mereka tetap memperhatikan agama sebagai bagian dari jati diri yang mereka bangun. Generasi $\mathrm{Z}$ memanfaatkan media agama online sebagai cara mereka untuk memperoleh pengetahuan karena itu lebih cocok dengan kondisinya. Selanjutnya, mereka dapat mengakses pengetahuan kapan saja dan di mana-mana karena mereka tidak punya cukup waktu untuk menghadiri pengajian. ${ }^{52}$ Muslim generasi Z di Banjarmasin 100\% menyatakan percaya bahwa Allah adalah satu-satunya Tuhan dan percaya pada rukun iman. Mereka juga mengaku sebanyak 99.3\% setuju dan sangat setuju mencoba selalu menaati perintah agama dan menjauhi larangan agama. Responden juga menyatakan 86.6\% dari mereka selalu menjaga salat lima waktu dan 98\% selalu berpuasa Ramadhan.

Dalam penilitian ini dibuktikan bahwa semakin religius seseorang maka akan semakin rendah keinginannya untuk membeli produk skin care tanpa label halal. Ini sejalan dengan teori kesalehan sosial. Kesalehan sosial adalah perwujudan dari kesalehan individual, sebab kesalehan individual tidak akan memiliki makna apa pun, jika tidak dapat menciptakan kesalehan dalam realitas sosialnya. Itulah makna hakiki dari kehidupan yang religius. Islam adalah agama yang selalu mempertautkan antara kedua kesalehan tersebut. Islam menggambarkan orang yang bertakwa selain beriman kepada Allah, hari akhir, kitab dan kepada para nabi, serta mendirikan salat (kesalehan religius), juga mau memberikan harta yang dicintainya kepada kerabatnya, memastikan harta itu halal dan membelanjakan untuk sesuatu yang halal serta dengan jalan yang halal pula (kesalehan sosial atau dalam kata lain muamalah)..$^{3}$

Dengan demikian dapat dijelaskan bahwa kesalehan sosial atau muamalah dalam Islam sesungguhnya merupakan aktualisasi atau perwujudan iman dalam praksi kehidupan sosial. Terma seperti tauhid sosial menunjukkan pengertian dari kesalehan sosial tersebut, yakni aktualisasi tauhid (iman) atau ibadah sehari-hari dalam praksis kehidupan sosial muamalah ( $a$ faith of social action $).{ }^{54}$

Hal ini sesuai dengan teori maslahah dalam konsumsi. Muslim sangat memperhatikan kualitas dan kesucian komoditas konsumsi yang termanifestasi dalam Alquran dan hadis, karena itu kepuasan (kesejahteraan) seorang konsumen Muslim sangat ditentukan oleh kadar kehalalan dan keharaman komoditas konsumsi. Ketika seorang konsumen Muslim dihadapkan pada pilihan komoditas halal- haram, maka sebagai Muslim dia harus mengambil keputusan untuk membeli dan menggunakan komoditas halal saja agar dapat meraih maslahah secara optimal. Artinya ketika seorang Muslim memiliki pendapatan yang sudah dikurangi dengan

\footnotetext{
51 Ita Syamtasiyah Ahyat, "Perkembangan Islam Di Kesultanan Banjarmasin," SOSIOHUMANIKA: Jurnal Pendidikan Sains Sosial Dan Kemanusiaan 8, no. 1 (2015): 11-20. hlm. 19.

${ }^{52}$ Haira Rizka, "Generation Z on the Choice of Religious Authorities: A Case Study of Religious Communities in Yogyakarta," Shabih 4, no. 1 (2019): 25-38.

${ }^{53}$ Dadang Kahmad, Sosiologi Agama: Potret Agama Dalam Dinamika Konflik, Pluralisme Dan Modernitas (Bandung: Pustaka Setia, 2011). hlm. 90-91.

${ }^{54}$ Kahmad. hlm. 92.
} 
pengeluaran dijalan Allah, maka seluruh pendapatannya itu harus dibelanjakan hanya untuk komoditas halal (disebut corner solution). ${ }^{55}$

\section{Gambar 3. Corner Solution Dalam Pilihan Komoditas Halal-Haram Dengan Optimal Utilitas}
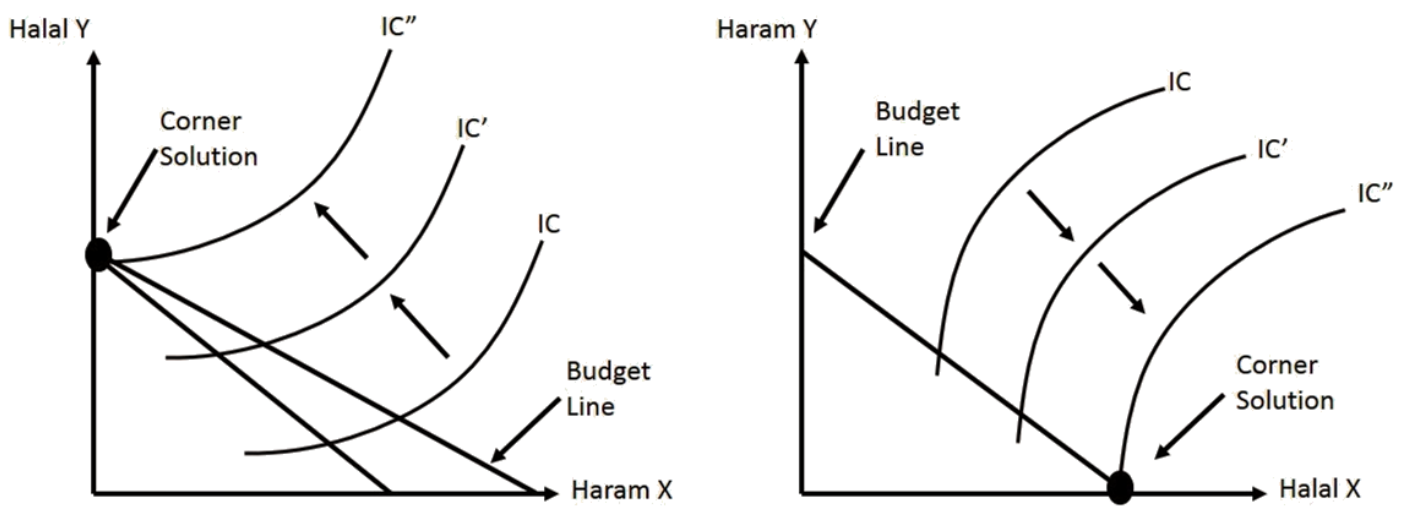

Ini sejalan pula dengan hasil dari penelitian Firmansyah, Purnamasari dan Djakfar dimana religiusitas mampu memperkuat pengaruh variabel lingkungan terhadap keputusan pembelian produk ramah lingkungan disebabkan karena religiusitas berhubungan dengan nilai-nilai spiritual yang memengaruhi tindakan seseorang dalam mengambil keputusan. Religiusitas sangat penting dalam kehidupan seseorang sehingga generasi $Z$ yang memiliki tingkat religiusitas tinggi dalam kesimpulan Firmansyah, Purnamasari dan Djakfar akan memikirkan lingkungan atas tindakan yang dilakukannya selama melakukan kegiatan pembelian. ${ }^{56}$

Begitu pula dengan penelitian Pramintasari dan Fatmawati yakni variabel keyakinan religius memiliki pengaruh yang signifikan terhadap kesadaran halal. ${ }^{57}$ Keyakinan religius umat Islam pada agamanya dapat mempengaruhi tingkat kesadaran pada produk halal, sehingga hasil dari penelitian ini sesuai dengan teori yang ada dan konsisten dengan hasil penelitian sebelumnya. Dari hasil penelitian tersebut, dapat dijadikan sebagai acuan bahwa keyakinan religius yang terdapat dalam diri seseorang dapat menjadi bahan pertimbangan dan mempengaruhi tingkat kesadaran halal ketika akan memilih atau mengkonsumsi produk. Semakin baik atau tinggi keyakinan religius yang dimiliki oleh seseorang, maka akan meningkatkan kesadaran halal dalam dirinya. Penelitian ini juga membuktikan, sebaliknya semakin baik atau tinggi keyakinan religius yang dimiliki oleh seseorang, maka akan menurunkan keinginan untuk membeli skin care tanpa label halal dalam dirinya. Dalam hal ini, agama menjadi faktor penghambat dari keputusan pembelian skin care tanpa label halal. Tidak adanya label halal pada produk skin care

55 Rini Elvira, "Pengaruh Persepsi Konsumen Muslim Tentang Maslahah Terhadap Keputusan Konsumsi Terbatas Hanya Pada Komoditas Halal (Studi: Mahasiswa Fakultas Syariah Dan Ekonomi Islam Tahun 2015)," Manbaj 04, no. 02 (2016): 177-87.

56 Firmansyah, Purnamasari, and Djakfar, "Religiusitas, Lingkungan Dan Pembelian Green Product Pada Konsumen Generasi Z.”

57 Talisa Rahma Pramintasari and Indah Fatmawati, "Pengaruh Keyakinan Religius, Peran Sertifikasi Halal, Paparan Informasi, Dan Alasan Kesehatan Terhadap Kesadaran Masyarakat Pada Produk Makanan Halal," Jurnal Manajemen Bisnis 8, no. 1 (2017): 734-66. 
membuat konsumen Muslim generasi $\mathrm{Z}$ di Banjarmasin ragu akan kehalalan produk tersebut dan akhirnya mendorong konsumen tersebut untuk tidak melakukan pembelian.

Dari paparan analisa hasil temuan studi ini dapat digunakan bagi produsen skin care agar memastikan sasaran konsumennya mengetahui bahwa produk yang mereka jual adalah produk yang halal dan baik, serta memasarkan produknya dengan label halal yang dapat dilihat konsumen secara jelas seperti saat iklan, brosur, dan tampilan produk di internet memberikan informasi kehalalan produk tersebut. Selain itu hasil dari penelitian ini memberikan manfaat terhadap perkembangan keilmuan atau kontribusi teoritis yang mengidentifikasi mengenai adanya pengaruh persepsi dan pengaruh tingkat religiusitas terhadap perilaku konsumsi berencana (Theory of planned behavior) dalam melakukan pembelian produk skin care pada generasi $\mathrm{Z}$ di Banjarmasin. Ini menjelaskan bahwa teori ini masih berlaku pada generasi remaja dan anak muda di kota Banjarmasin. Temuan dari penelitian ini juga menambahkan dukungan pada teori maslahah dalam konsumsi pada Ekonomi Islam.

\section{Kesimpulan}

Berdasarkan hasil penelitian yang didapatkan, dapat disimpulkan bahwa persepsi Muslim generasi $\mathrm{Z}$ di Banjarmasin berpengaruh secara signifikan terhadap keputusan pembelian produk skin care tanpa label halal, sedangkan religiusitas tidak berpengaruh secara signifikan terhadap keputusan pembelian skin care tanpa label halal. Keputusan pembelian skin care tanpa label halal dapat ditentukan berdasarkan seberapa besar persepsi pribadi seseorang terhadap produk skin care tersebut. Persepsi dan keputusan pembelian skin care tanpa label halal memiliki hubungan positif, sehingga semakin kuat persepsi seseorang, semakin kuat pula orang tersebut memutuskan untuk membeli skin care tanpa label halal. Sementara religiusitas dan keputusan pembelian produk skin care tanpa label halal memiliki hubungan negatif, sehingga semakin tinggi religiusitas seseorang, maka semakin rendah orang tersebut memutuskan untuk membeli skin care tanpa label halal.

Pada simpulan ini peneliti mencoba untuk memberikan beberapa saran. Generasi Z yang merupakan generasi melek teknologi informasi yang dapat mengakses informasi secara cepat hendaknya tidak selalu berpegang pada persepsi pribadi mereka akan suatu produk skin care dan tidak hanya melihat ulasan dari para social influencer. Bagi para konsumen hendaknya mempertimbangkan skin care yang sudah berlabel halal untuk menghilangkan keraguan mengingat banyaknya produk tanpa label halal yang beredar di Indonesia.

Saran bagi para peneliti selanjutnya agar dapat menggunakan variabel-variabel bebas lain selain persepsi dan religiusitas, sehingga dapat diketahui faktor-faktor lain yang memengaruhi keputusan pembelian. Penelitian ini memiliki keterbatasan yaitu pengambilan data hanya di satu wilayah yaitu Banjarmasin. Penelitian selanjutnya dapat menggunakan responden dari beberapa wilayah di Kalimantan Selatan, sehingga dapat dibandingkan hasilnya. Penelitian selanjutnya juga dapat menambahkan responden dari generasi yang berbeda, yaitu generasi $\mathrm{X}$ ataupun generasi $\mathrm{Y}$ sehingga dapat dibedakan consumer behavior antar generasi.

\section{Daftar Pustaka}

Adiba, Elfira Maya, and Dewi Ayu Wulandari. "Pengaruh Halal Knowledge, Islamic Religiosity, Dan Attitude Terhadap Behavior Konsumen Muslim Generasi Y Pengguna Kosmetik Halal Di Surabaya." INOBIS: Jurnal Inovasi Bisnis Dan Manajemen Indonesia 1, no. 3 (2018): 357-69. https://doi.org/10.31842/jurnal-inobis.v1i3.42. 
Ahyat, Ita Syamtasiyah. "Perkembangan Islam Di Kesultanan Banjarmasin." SOSIOHUMANIKA: Jurnal Pendidikan Sains Sosial Dan Kemanusiaan 8, no. 1 (2015): $11-20$.

Amanu, Ananda Abdillah. "Analisis Perilaku Pembelian Kosmetik Halal Berdasarkan Theory of Planned Behaviour (Studi Kasus Mahasiswa Perguruan Tinggi Agama Islam Swasta Yogyakarta).” UII Yogyakarta. Universitas Islam Indonesia, 2018.

Badan Pusat Statistik. Profil Generasi Milenial Indonesia. Jakarta: Kementrian Pemberdayaan Perempuan dan Perlindungan Anak, 2018. https://www.kemenpppa.go.id/lib/uploads/list/9acde-buku-profil-generasimilenia.pdf.

Calder, Bobby J, and Robert E. Burnkrant. "Interpersonal Influence on Cosumer Behavior: An Attribution Theory Approach.” Journal of Consumer Research 4, no. 1 (1977): 29-38.

Eliot Simangunsong. "Generation-Z Buying Behaviour in Indonesia: Opportunities for Retail Businesses." MIX: Jurnal Ilmiah Manajemen 8, no. 2 (2018): 243-53. https://www.researchgate.net/profile/Eliot_Simangunsong/publication/32724760 6_Generation-

Z_Buying_Behaviour_in_Indonesia_Opportunities_for_Retail_Businesses/links/5 b890178a6fdcc5f8b734819/Generation-Z-Buying-Behaviour-in-IndonesiaOpportunities-for-Retail.

Elvira, Rini. "Pengaruh Persepsi Konsumen Muslim Tentang Maslahah Terhadap Keputusan Konsumsi Terbatas Hanya Pada Komoditas Halal (Studi: Mahasiswa Fakultas Syariah Dan Ekonomi Islam Tahun 2015).” Manhaj 04, no. 02 (2016): 177-87.

Firmansyah, Fani, Puji Endah Purnamasari, and Muhammad Djakfar. "Religiusitas, Lingkungan Dan Pembelian Green Product Pada Konsumen Generasi Z." IQTISHODUNA 15, no. 1 (2019): 57-70. https://doi.org/.1037//00332909.I26.1.78.

Hashim, Azreen Jihan bt Che Mohd, and Rosidah Musa. "Factors Influencing Attitude towards Halal Cosmetic among Young Adult Urban Muslim Women: A Focus Group Analysis." Procedia - Social and Behavioral Sciences 130 (2014): 129-34. https://doi.org/10.1016/j.sbspro.2014.04.016.

Indonesia, Presiden Republik. Undang-Undang Republik Indonesia Nomor 33 Tahun 2014 Tentang Jaminan Produk Halal, Pub. L. No. 33 (2014).

Jeff Fromm. "The Influence of Identity: What Gen Z Wants from the Beauty Industry | Millennial Marketing." Millennial Marketing, 2018. http://www.millennialmarketing.com/2018/01/the-influence-of-identity-whatgen-z-wants-from-the-beauty-industry/.

Kahmad, Dadang. Sosiologi Agama: Potret Agama Dalam Dinamika Konflik, Pluralisme Dan Modernitas. Bandung: Pustaka Setia, 2011.

Khaeruman, Badri. Hukum Islam Dalam Perubahan Sosial. Bandung: Pustaka Setia, 2010.

LPPOM MUI. "Mengapa Kosmetika Harus Halal?" LPPOM MUI, 2017. http://www.halalmui.org/mui14/index.php/main/detil_page/138/23627.

LPPOM MUI Pusat. Daftar Belanja Produk Halal. Jakarta: LPPOM MUI Pusat, 2019. http://www.halalmui.org/mui14/images/daftarprodukhalal.pdf. 
Madden, Thomas J, Pamela Scholder Ellen, and Icek Ajzen. "A Comparison of The Theory of Planned Behaviour and The Theory of Reasoned Action." Personality and Social Psychology Bulletin 18, no. 1 (1992): 3-9.

Muflih, Muhammad. Perilaku Konsumen Dalam Perspektif Ilmu Ekonomi Islam. Jakarta: Raja Grafindo Persada, 2006.

Niswah, Farokhah Muzayinatun. "Hubungan Persepsi Dan Religiusitas Terhadap Keputusan Pembelian Kosmetik Tanpa Label Halal.” Jurnal Middle East and Islamic Studies 6, no. 1 (2018): 1-20.

Penzer, Rebecca, and Steven Ersser. Principles of Skin Care: A Guide for Nurses and Health Care Practitioners. Malaysia: John Wiley \& Sons, 2010.

pewforum.org. "Indonesia Religion: Demographics and Religion | PEW-GRF." Pew Research Center, 2019. http://www.globalreligiousfutures.org/countries/indonesia\#/?affiliations_religion $\_$id $=0 \&$ affiliations_year $=2010 \&$ region_name $=$ All

Countries\&restrictions_year $=2016$.

Pramintasari, Talisa Rahma, and Indah Fatmawati. "Pengaruh Keyakinan Religius, Peran Sertifikasi Halal, Paparan Informasi, Dan Alasan Kesehatan Terhadap Kesadaran Masyarakat Pada Produk Makanan Halal.” Jurnal Manajemen Bisnis 8, no. 1 (2017): 734-66.

Qardhawi, Yusuf Al. Peran Nilai Dan Moral Dalam Perekonomian Islam. Jakarta: Robbani Press, 2001.

Rizka, Haira. "Generation Z on the Choice of Religious Authorities: A Case Study of Religious Communities in Yogyakarta." Shabih 4, no. 1 (2019): 25-38.

Rosida, Rida. "Faktor-Faktor Yang Mempengaruhi Intensi Pembelian Kosmetik Halal (Survey Pada Muslimah Di Jawa Barat)." Jurnal Ekonomi Dan Bisnis Islam (Journal of Islamic Economics and Business) 4, no. 2 (2018): 129-40. https://doi.org/10.20473/jebis.v4i2.10501.

Simamora, Bilson. Panduan Riset Perilaku Konsumen. Jakarta: Gramedia Pustaka Utama, 2008.

Suharyadi, and Purwanto S.K. Statistika Untuk Ekonomi Dan Keuangan Modern Buku 2. 3rd ed. Jakarta: Salemba Empat, 2017.

Sumarwan, Ujang. Perilaku Konsumen: Teori Dan Penerapannya Dalam Pemasaran. Bogor: Ghalia Indonesia, 2011.

Wahyuningsih, Indah. "Intensi Konsumen Terhadap Kosmetik Dan Produk Skincare Halal Di Indonesia: Pendekatan Theory of Planned Behavior." JEBA (Journal of Economics and Business Aseanomics) 3, no. 1 (2018): 41-59. https://doi.org/10.33476/jeba.v3i1.741.

Wigati, Sri. "Perilaku Konsumen Dalam Perspektif Ekonomi Islam.” Maliyah 01, no. 01 (2011): 22-39. 